\title{
What contributes to micro, small, and medium enterprises' productivity in fisheries sector in Aceh, Indonesia?
}

\author{
M. Shabri Abd. Majid ${ }^{1 *}$, Faisal Faisal ${ }^{2}$, Heru Fahlevi ${ }^{3}$, A Azhari ${ }^{4}$, and Hijri Juliansyah ${ }^{5}$ \\ ${ }^{1}$ Department of Economics, Faculty of Economics and Business, Universitas Syiah Kuala, Banda Aceh, Indonesia. \\ ${ }^{2}$ Department of Management, Faculty of Economics and Business, Universitas Syiah Kuala, Banda Aceh, Indonesia. \\ ${ }^{3}$ Department of Accounting, Faculty of Economics and Business, Universitas Syiah Kuala, Banda Aceh, Indonesia. \\ ${ }^{4}$ Program Study of Master of Management, Faculty of Economics and Business, Universitas Islam Kebangsaan Indonesia. \\ ${ }^{5}$ Department of Economics, Faculty of Economics and Business, Universitas Malikussaleh, Lhokseumawe, Indonesia.
}

\begin{abstract}
Although Micro, Small, and Medium Enterprises (MSMEs) engaged in the agricultural, livestock, forestry, and fishery sector was recorded as the second-largest contributor to the Indonesian economy in the last decade, but their productivity level was relatively low due to their small-scale business entity. To further enhance their contribution to the national economy, MSMEs needs to enhance their productivity. This study measures Total Factor Productivity (TFP) of the MSMEs in the fisheries sector across 23 districts/cities in Aceh province, Indonesia over the period from 2015 to 2019 period. The study also decomposes the TFP into its sources. Using Data Envelopment Analysis (DEA), the study documented a low level of MSMEs' TFP during the study period. The MSMEs experienced different levels of TFP. Overall, the MSMEs experienced a decline in their TFP level, contributed mainly by the deteriorations in the efficiency and technical efficiency levels. These findings indicated the urgent call for adopting advanced fisheries-related technologies and implementing good MSMEs' governance practices to further promote MSMEs' performance. Finally, the relevant government authorities are suggested to prioritize promoting less productive MSMEs in the province by providing adequate financial assistance and conducting regular professional entrepreneurial workshops, short courses, and training programs.
\end{abstract}

\section{Introduction}

Micro, Small, and Medium Enterprises (MSMEs) play a crucial role in the Indonesian economy. The contribution of MSMEs to the national economy has been increasing over the last decades. Apart from offering new job opportunities, MSMEs contribute to income disparity reduction and poverty alleviation. MSMEs are viewed as an engine of national economic growth as they promote foreign exchange income for the country through exports' expansion of MSMEs products to the foreign markets. Ministry of Cooperatives and SMEs reported that the existing 61.7 million units of MSMEs in 2016 have contributed $89.2 \%$ job opportunities to the labor market, $60.34 \%$ to the total national economy, $14.17 \%$ to the total exports, and $58.18 \%$ to the total investment [1]. The MSMEs' contributions to the Indonesian economy showed a growing trend. In 2020, the existing 64.2 million units of MSMEs contributed $61.07 \%$ to the national economy, $97 \%$ to the labor market, and $60.4 \%$ to the total national investment [2].

MSMEs engaged in the fisheries sector are among the leading small-scale business entities that contribute to the national economy. In 2014, MSMEs in the fisheries sector contributed $48.85 \%$ to the national GDP [3]. In the second quarter of 2021, the MSMEs in the agricultural, livestock, forestry, and fishery sector was documented as the second-largest contributor to the Indonesian economy [4]. As a maritime country, Aceh is one of the provinces in Indonesia that has great agribusiness potential in the fisheries sector [5]. Aceh is a province that has a long coastline with a water area of 295,370 km2 [6]. The geographical location of Aceh which borders the seacoast has encouraged the growth of MSMEs in the fisheries sector in Aceh Province. During the 2011-2018 period, the average yield of captured fish and fisherman cultivation in Aceh continued to show an increasing trend, respectively, by $9.60 \%$ and $12.79 \%$ [7].

The rising contribution of MSMEs to the national economy is very much related to labor productivity. Many previous studies have discovered determinants of MSMEs' productivity worldwide [8]. For instance, previous studies documented the significant role of labor, skills, and technology in the productivity of MSMEs in India [9]. Operational, products and services' innovation contributed to the MSMEs' productivity in Italy [10]. Financial supports determined the productivity of MSMEs in the Arab region [11], while

\footnotetext{
*Corresponding author: mshabri@unsyiah.ac.id
} 
infrastructure access and competitive ability influenced MSMEs' productivity in Africa [12]. Credit availability has constrained MSMEs in Canada to improve their productivity level [13].

Many previous studies have also explored MSMEs' productivity in the ASEAN economies. For example, the improved productivity of MSMEs in Vietnam was primarily caused by their ability to secure a globally recognized certificate and to innovate products technologically [14]. The utilization of information and communication technology, tax incentives, and product innovation promoted the productivity of MSMEs in Thailand [15]. Meanwhile, the productivity of MSMEs in Semarang, Indonesia is influenced by entrepreneurial competencies, professional management, technology, innovation, and business networks [16]. Other studies documented that human resources [17], training [18], the proper mix of inputs [19], technology, financial adequacy [20], economies of scale, level of education [21] and [22], and the adoption of updated technology [23] and [24] were among the crucial determinants of Indonesian MSMEs' productivity.

To our knowledge, although the above-reviewed researches have explored the factors determining MSMEs' productivity, but we found no studies have assessed the MSMEs' productivity in the fisheries sector in Indonesia. Besides, previous studies have not evaluated the sources of MSMEs' productivity; therefore, they failed to offer comprehensive policydesigned ramifications to further enhance MSMEs' productivity. Finally, different from previous studies that focused their analyses only on specific MSMEs in a certain district in Indonesia, this study measures the relative TFP and its sources, taking the case of MSMEs in the fisheries sector across 23 districts/cities in Aceh province, Indonesia. Intended to fill the gaps in the previous researches, this study aims to measure the Total Factor Productivity (TFP) of MSMEs in the fisheries sector and identifies its TFP's sources using the Data Envelopment Analysis (DEA). Using the DEA approach enables us to measure TFP and its decompositions into efficiency change (i.e., pure efficiency and scale efficiency changes) and technical change. The findings of this study are hoped to offer the latest evidence for the SMEs and relevant government authorities in formulating policies to enhance SMEs' productivity.

\section{$2 \quad$ Materials and Methods}

\subsection{Site and time}

This study empirically measures and decomposes the sources of TFP of MSMEs in the fisheries sector across 23 districts/cities in Aceh province, Indonesia over the period from 2015 to 2019. According to the Law No. 9 of 1985 and Law No. 45 of 2009 of the Republic Indonesia concerning Fisheries, MSMEs in this sector involve individual or legal entity businesses to catch or cultivate fish, including activities to store, cool, dry, or preserve fish to create added economic value for business actors (commercial business).

\subsection{Sampling and measurements}

Of 2,178 units of MSMEs in the fisheries sector in 23 districts/cities in Aceh province, Indonesia, 138 of them were selected as the sample of study using a stratified random sampling technique. These comprise six units of MSMEs in every 23 regencies/cities. Since the study covers a period of five years, thus the study analyzes 690 observations. In measuring TFP and its decompositions of the MSMEs in the fisheries sector, this study uses three inputs, namely: number of managerial board, own capital, and external capital, and managerial board, and one output, namely: total profit. The inputs-output determination is referred to the Indonesian Co-operative Act, No. 25 (1992). According to the Act, the operationalization of the MSMEs is supported by own capital, external capital, and managerial members for the business to grasp profit. Thus, the study gathers primary data using the questionnaires' distribution to the selected sample in Aceh province, Indonesia.

\subsection{Data and Analysis}

In measuring the TFP of Decision-Making Units (DMUs) and identify its sources, three approaches, namely traditional, parametric, and non-parametric analyses have been commonly adopted by previous researchers [8]. A non-parametric approach of DEA has been the popular approach used to measure of TFP of the DMUs due to its strengths [25]. DEA is not only able to identify the sources of TFP, but it is also able to measure TFP through the combination of multiple inputs to produce various outputs [26] using assumptions of both Constant Return to Scale (CRS) and Variable Return to Scale (VRS). Unlike the CRS model, the VRS assumes the ratio of inputs and outputs changes are disproportionate, showing that a change in inputs by $\mathrm{x}$ percentage could cause changes in the output by more or less than $x$ percentage [27].

On these grounds, thus this study measures the relative TFP of the MSMEs in the fisheries sector using a generalized output-orientation of the Malmquist index [28]. Using the DEA statistical software, the study measures the following equations:

$$
M_{0}\left(x^{t}, y^{t}, x^{t+1}, y^{t+1}\right)=(a) x(b)
$$

where

$$
\begin{array}{r}
a=\frac{D_{0}^{t}\left(x^{t+1}, y^{t+1}\right)}{D_{0}^{t}\left(x^{t}, y^{t}\right)} ; \text { and } \\
b=\frac{D_{o}^{t}\left(x^{t+1}, y^{t+1}\right)}{D_{o}^{t}\left(x^{t}, y^{t}\right)}
\end{array}
$$

where M0 is the Malmquist Index of TFP; Do is a function of distance; $\mathrm{x}$ and $\mathrm{y}$ are inputs and output for periods $t$ and $t+1$, respectively; $a$ is a technical change; and $b$ is an efficiency change.

The study decomposes the TFP into two components, namely: efficiency change (EFch) and technical efficiency change (TEch). EFch is further decomposed into two sub-components, namely: pure efficiency change (PEch) and scale efficiency change (SEch). The following equations are used to decompose 
the sources of MSMEs' TFP in the fisheries sector in Aceh Province, Indonesia:

$$
M_{0}\left(x^{t}, y^{t}, x^{t+1}, y^{t+1}\right)=(a) x(b)=(a) x(c x d)
$$

where

$$
\begin{gathered}
a=\left[\left(\frac{D_{0}^{t+1}\left(x^{t}, y^{t}\right)}{D_{0}^{t}\left(x^{t}, y^{t}\right)}\right)\left(\frac{D_{0}^{t+1}\left(x^{t+1}, y^{t+1}\right)}{D_{0}^{t}\left(x^{t+1}, y^{t+1}\right)}\right)\right]^{1 / 2} \\
c=\left(\frac{D_{0}^{t}\left(x^{t}, y^{t}\right)}{D_{0}^{t+1}\left(x^{t+1}, y^{t+1}\right)}\right) ; \text { and } \\
d=\left(\frac{D_{o c}^{t+1}\left(x^{t}, y^{t}\right)}{D_{0}^{t+1}\left(x^{t}, y^{t}\right)} \frac{D_{0}^{t+1}\left(x^{t+1}, y^{t+1}\right)}{D_{o c}^{t+1}\left(x^{t+1}, y^{t+1}\right)} \frac{D_{o c}^{t}\left(x^{t}, y^{t}\right)}{D_{0}^{t}\left(x^{t}, y^{t}\right)} \frac{D_{0}^{t}\left(x^{t+1}, y^{t+1}\right)}{D_{o c}^{t}\left(x^{t+1}, y^{t+1}\right)}\right)^{1 / 2}
\end{gathered}
$$

$a$ is the technical change (TEch); $b$ is the change in efficiency; $c$ is the change in pure efficiency (PEch); and $\mathrm{d}$ is the change in scale efficiency (SEch).

\section{$3 \quad$ Results and discussion}

Table 1 reports the relative efficiency of MSMEs in the fisheries sector across 23 districts/cities in Aceh province, Indonesia over the period from 2015 to 2019 based on the Constant Return to Scale (CSR) and Variable Return to Scale (VRS) assumptions.

As illustrated in Table 1, the MSMEs recorded the highest efficiency (62.4\%) in 2015 based on the VRS and in 2016 (53.4\%) based on CSR. From the year 2016 onwards, the MSMEs experienced a declining trend in their efficiency level up to the lowest level in 2019 (CRS $=44.2 \%$ and $\mathrm{VRS}=54.6 \%$ ). During the study period, on average, based on the CRS and VRS models, the MSMEs recorded efficiency levels of $49.1 \%$ and $58.3 \%$, respectively. These findings show a low level of efficiency of the MSMEs in the fisheries sector in Aceh, Indonesia.

Table 1 also shows that, based on the CRS assumption, the study found that MSMEs in Lhokseumawe recorded the lowest efficiency level $(15.04 \%)$, followed by MSMEs in the districts of Simeulue $(17.06 \%)$, Pidie $(18.56 \%)$, East Aceh $(21.32 \%)$, and Aceh Singkil (21.36\%). On the other hand, the MSMEs in the districts of Bireuen and Aceh Tamiang recorded an optimal efficient level (100\%), followed by Benar Meriah (89.78\%), Southwest Aceh (89.7\%), Banda Aceh (71.82\%), and Central Aceh (70.88\%).

From the perspective of the VRS estimates, the study found that MSMEs in six districts/cities (i.e., Banda Aceh, North Aceh, Bireuen, Aceh Tamiang, Sabang, and Southwest Aceh) experienced a full efficient level $(100 \%)$ during the study period. Meanwhile, the MSMEs in Lhoksuemawe recorded the worst level of efficiency $(15.6 \%)$, followed by MSMEs in the districts/cities of Simeulue (19.2\%), Aceh Singkil $(21.9 \%)$, East Aceh (23.2\%), and Pidie (23.4\%). Of 138 MSMEs investigated in the study, MSMEs in Bireuen and Aceh Tamiang have been able to operate at their optimal efficiency level both based on the CRS and VRS models. Our findings showed the dissimilar level of efficiency of MSMEs across 23 districts/cities in Aceh Province.

Table 1. CRS and VRS of the SMEs in the fisheries sector, 2015-2019.

\begin{tabular}{|l|c|c|c|c|c|c|c|c|c|c|}
\hline \multirow{2}{*}{ District } & \multicolumn{2}{|c|}{$\mathbf{2 0 1 5}$} & \multicolumn{2}{c|}{$\mathbf{2 0 1 6}$} & \multicolumn{2}{c|}{$\mathbf{2 0 1 7}$} & \multicolumn{2}{c|}{$\mathbf{2 0 1 8}$} & \multicolumn{2}{c|}{$\mathbf{2 0 1 9}$} \\
\cline { 2 - 12 } & CRS & VRS & CRS & VRS & CRS & VRS & CRS & VRS & CRS & VRS \\
\hline Banda Aceh & 0.28 & 1 & 1 & 1 & 1 & 1 & 1 & 1 & 0.31 & 1 \\
\hline Aceh Besar & 0.56 & 0.63 & 0.63 & 0.66 & 0.6 & 0.8 & 0.71 & 0.73 & 0.91 & 0.91 \\
\hline Pidie & 0.12 & 0.16 & 0.22 & 0.22 & 0.35 & 0.47 & 0.12 & 0.17 & 0.12 & 0.15 \\
\hline Pidie Jaya & 0.79 & 0.99 & 1 & 1 & 0.41 & 0.56 & 0.32 & 0.45 & 0.33 & 0.41 \\
\hline Bireuen & 1 & 1 & 1 & 1 & 1 & 1 & 1 & 1 & 1 & 1 \\
\hline Lhokseumawe & 0.16 & 0.18 & 0.19 & 0.19 & 0.15 & 0.15 & 0.15 & 0.16 & 0.11 & 0.11 \\
\hline North Aceh & 0.44 & 1 & 0.54 & 1 & 0.25 & 1 & 0.6 & 1 & 0.18 & 1 \\
\hline East Aceh & 0.06 & 0.08 & 0.24 & 0.24 & 0.28 & 0.31 & 0.49 & 0.51 & 0.01 & 0.01 \\
\hline Langsa & 0.25 & 0.26 & 0.21 & 0.24 & 0.17 & 0.25 & 0.47 & 0.63 & 0.36 & 0.54 \\
\hline Aceh Tamiang & 1 & 1 & 1 & 1 & 1 & 1 & 1 & 1 & 1 & 1 \\
\hline Southeast Aceh & 0.2 & 0.26 & 0.43 & 0.46 & 0.66 & 0.7 & 0.66 & 0.67 & 0.35 & 0.59 \\
\hline Gayo Lues & 0.5 & 0.51 & 0.4 & 0.4 & 0.49 & 0.49 & 0.46 & 0.46 & 0.51 & 0.51 \\
\hline Central Aceh & 1 & 1 & 1 & 1 & 0.54 & 0.66 & 0.3 & 0.42 & 0.7 & 0.83 \\
\hline Bener Meriah & 0.89 & 1 & 1 & 1 & 1 & 1 & 0.86 & 0.92 & 0.74 & 0.78 \\
\hline Aceh Singkil & 0.21 & 0.22 & 0.25 & 0.25 & 0.18 & 0.18 & 0.2 & 0.21 & 0.24 & 0.24 \\
\hline Sabang & 0.66 & 1 & 0.51 & 1 & 0.28 & 1 & 0.63 & 1 & 0.3 & 0.3 \\
\hline
\end{tabular}




\begin{tabular}{|l|c|c|c|c|c|c|c|c|c|c|}
\hline \multirow{2}{*}{ District } & \multicolumn{2}{|c|}{2015} & \multicolumn{2}{c|}{$\mathbf{2 0 1 6}$} & \multicolumn{2}{c|}{$\mathbf{2 0 1 7}$} & \multicolumn{2}{c|}{2018} & \multicolumn{2}{c|}{2019} \\
\cline { 2 - 13 } & CRS & VRS & CRS & VRS & CRS & VRS & CRS & VRS & CRS & VRS \\
\hline West Aceh & 0.36 & 0.37 & 0.42 & 0.42 & 0.4 & 0.4 & 0.43 & 0.43 & 0.56 & 0.56 \\
\hline Nagan Raya & 0.22 & 0.25 & 0.23 & 0.25 & 0.22 & 0.3 & 0.2 & 0.25 & 0.24 & 0.29 \\
\hline Southwest Aceh & 0.83 & 1 & 0.94 & 1 & 0.71 & 1 & 1 & 1 & 1 & 1 \\
\hline South Aceh & 1 & 1 & 0.17 & 0.17 & 0.25 & 0.29 & 0.26 & 0.27 & 0.29 & 0.3 \\
\hline Subussalam & 0.29 & 0.33 & 0.23 & 0.23 & 0.26 & 0.35 & 0.23 & 0.3 & 0.3 & 0.41 \\
\hline Simeulue & 0.13 & 0.13 & 0.15 & 0.16 & 0.2 & 0.23 & 0.22 & 0.23 & 0.17 & 0.2 \\
\hline Aceh Jaya & 0.86 & 1 & 0.57 & 0.69 & 0.39 & 0.42 & 0.17 & 0.17 & 0.44 & 0.44 \\
\hline Mean & 0.51 & 0.62 & 0.53 & 0.59 & 0.47 & 0.59 & 0.5 & 0.56 & 0.44 & 0.55 \\
\hline
\end{tabular}

Source: Primary data processed using the DEA program (2021).

Table 2. TFP changes and its sources of the SMEs in the fisheries sector, 2015-2019.

\begin{tabular}{|c|c|c|c|c|c|}
\hline \multirow{2}{*}{ District } & \multicolumn{5}{|c|}{ 2015-2019 } \\
\hline & EFch & TEch & PEch & SEch & TFPch \\
\hline Banda Aceh & 1.024 & 0.903 & 1 & 1.024 & 0.924 \\
\hline Aceh Besar & 1.131 & 0.978 & 1.098 & 1.03 & 1.106 \\
\hline Pidie & 0.991 & 0.887 & 0.982 & 1.009 & 0.879 \\
\hline Pidie Jaya & 0.8 & 0.865 & 0.801 & 0.999 & 0.693 \\
\hline Bireuen & 1 & 1.006 & 1 & 1 & 1.006 \\
\hline Lhokseumawe & 0.919 & 0.925 & 0.89 & 1.032 & 0.849 \\
\hline North Aceh & 0.8 & 0.915 & 1 & 0.8 & 0.732 \\
\hline East Aceh & 0.697 & 0.919 & 0.646 & 1.079 & 0.64 \\
\hline Langsa & 1.093 & 0.967 & 1.201 & 0.91 & 1.057 \\
\hline Aceh Tamiang & 1 & 0.922 & 1 & 1 & 0.922 \\
\hline Southeast Aceh & 1.151 & 0.969 & 1.23 & 0.936 & 1.116 \\
\hline Gayo Lues & 1.009 & 0.933 & 1 & 1.009 & 0.941 \\
\hline Central Aceh & 0.915 & 0.912 & 0.955 & 0.957 & 0.834 \\
\hline Bener Meriah & 0.955 & 0.912 & 0.94 & 1.017 & 0.871 \\
\hline Aceh Singkil & 1.032 & 0.93 & 1.013 & 1.019 & 0.96 \\
\hline Sabang & 0.821 & 0.943 & 0.74 & 1.109 & 0.774 \\
\hline West Aceh & 1.117 & 0.93 & 1.107 & 1.009 & 1.039 \\
\hline Nagan Raya & 1.021 & 0.984 & 1.034 & 0.987 & 1.005 \\
\hline Southwest Aceh & 1.047 & 0.992 & 1 & 1.047 & 1.038 \\
\hline South Aceh & 0.732 & 0.834 & 0.741 & 0.988 & 0.61 \\
\hline Subussalam & 1.006 & 0.972 & 1.055 & 0.954 & 0.978 \\
\hline Simeulue & 1.075 & 0.93 & 1.103 & 0.974 & 1 \\
\hline Aceh Jaya & 0.848 & 0.93 & 0.816 & 1.038 & 0.788 \\
\hline Mean & 0.956 & 0.932 & 0.961 & 0.995 & 0.891 \\
\hline
\end{tabular}

Source: Primary data processed using the DEA program (2021)

In addition, our study also indicated an unstable efficiency level of MSMEs, implying the inability of MSMEs' management to maintain and even continuously improve their efficiency level across the years. As a small scale-business entity that is not supported by adequate capital and modern management practices has contributed to the low level of efficiency of MSMEs in Aceh province, Indonesia.

Furthermore, Table 2 reports the TFP changes and its sources of the MSMEs in the fisheries sector in Aceh Province, Indonesia during the 2015-2019 period. TFP is decomposed into two main sources, namely: efficiency change (EFch) and technical efficiency change (Tech). The EFch is further decomposed into two sub-sources, namely: scale efficiency change (SEch) and pure efficiency change (PEch). The value of TFP change of greeter than 1.000 shows an improvement in the MSMEs' productivity, while the value of less than 1.00 shows a deterioration in the MSMEs' productivity.

As observed from Table 2, overall, the study found that the average TFP of the MSMEs in the fisheries 
sector has declined by $-10.9 \%$ during $2015-2019$. The declining trend of the TFP is contributed by a deterioration of efficiency change and technical change by $-4.4 \%$ and $-6.8 \%$, respectively. These findings show the lack of technical innovation of the MSMEs in the fisheries sector in Aceh, Indonesia. Furthermore, the reduction in the changes in the efficiency of the MSMEs was caused by pure efficiency and scale efficiency deteriorations by $-3.9 \%$ and $-0.5 \%$, respectively. The inability of the entrepreneurs in the fisheries sector to properly combine the right inputs to produce the highest level of outputs due to traditional management practices has been the main contribution to the declining in the relative efficiency and TFP of the MSMEs in Aceh Province, Indonesia.

Our findings of the low level of the MSME's efficiency and TFP levels of the fisheries sector in Aceh Province, Indonesia are in harmony with many existing empirical findings [29] and [30]. However, our findings of different MSMEs' efficiency and TFP levels contradicted the previous research that documented similar SMEs' productivity levels in 29 regions in mainland China [31].

Having different TFP levels of MSMEs across the districts/cities signifies the crucial efforts to be taken by the relevant government authorities, particularly the Offices of SMEs and Co-operatives to design proper policies to promote MSMEs TFP levels in all regions to experience a similar TFP level. The government should continuously take serious efforts to prioritize promoting MSMEs in the districts/cities that experienced a lower level of TFP by providing sufficient financial aids and improving professional entrepreneurial management skills and practices through various short courses, workshops, and training. This policy would create a just economic development across the cities/districts in the province. To further promote MSMEs' TFP, the government should suggest and provide the MSMEs with advanced fisheries-related technologies.

Finally, our empirical evidence of different MSMEs' TFP levels across the cities/districts are similar to previous studies [10], [14], [29], and [32-34]. In addition to providing financial aids, the relevant government authorities are suggested to provide regular professional entrepreneurial training, particularly for the MSMEs in the cities/districts that experienced the lower TFP levels by benchmarking the MSMEs' best practices from other districts/cities in the province.

Finally, the MSMEs should also continuously maximize the utilization of their human and financial resources for productive activities and combine properly limited inputs to produce the maximum level of outputs.

\section{Conclusions}

This study has measured and decomposed Total Factor Productivity (TFP) of the fisheries' MSMEs in across 23 regencies/cities in Aceh province, Indonesia during the 2015 to 2019 period. Using the Data Envelopment Analysis (DEA) analysis, the study recorded evidence of the low MSMEs' TFP level. Overall, the MSMEs have experienced a decline in their TFP level, contributed mainly by the deteriorations in efficiency and technical changes. In addition, the decline in technical efficiency has contributed most to the declining trend of the MSMEs' TFP. These empirical findings indicated the urgent call for adopting advanced fisheries-related technologies and implementing good MSMEs' governance practices to further promote MSMEs' performances. The MSMEs are also required to improve their human and financial resources for productive activities and properly combine limited inputs to produce the maximum outputs. Finally, the relevant government authorities should prioritize promoting less productive MSMEs across the districts/cities in the province by granting adequate financial supports and conducting regular professional entrepreneurial workshops, short courses, and training programs.

To provide more robust empirical evidence of the MSMEs' performance, future studies are suggested to investigate the MSMEs' TFP engaging in various economic sectors across districts/cities and provinces nationwide to produce a comprehensive picture of the MSMEs performance. Finally, future researches could adopt a mixed research method, covering both parametric and non-parametric to enrich the existing references and empirical results of the MSMEs performance.

Acknowledgement. This article is part of the research project funded by the Directorate General of Strengthening Research and Development, Ministry of Research, Technology and Higher Education, the Republic of Indonesia, under the scheme of the World Class Research No: 215/SP2H/LT/DPRM/2019.

\section{References}

1. BPS-Indonesian Statistics. Sensus Ekonomi. Jakarta: BPS (2016)

2. Ministry of Coordinator for Economic Affairs of the Republic of Indonesia. Press Release: UMKM menjadi pilar penting dalam perekonomian Indonesia [Internet]. Jakarta (2001). Available from: https://ekon.go.id/publikasi/detail/2969/ umkm-menjadi-pilar-penting-dalamperekonomian-indonesia

3. Bank Indonesia. Profil bisnis usaha mikro, kecil dan menengah (UMKM) [Internet]. Jakarta (2015). Available from: https://www.bi.go.id/id/umkm/ penelitian/Documents/Profil $\% 20$ Bisnis\%20UMKM.pdf

4. BPS- Indonesian Statistics. Annual Report. Jakarta (2021)

5. I. Nurdin. Tantangan pengelolaan potensi perikanan Aceh. AcehTrend.Com (Internet]. Aceh (2019). Available from: https://www.acehtrend.com/ 2019/05/23/tantangan-pengelolaan-potensiperikanan-aceh/

6. BPS- Indonesian Statistics. Provinsi Aceh dalam Angka 2018. Banda Aceh (2019) 
7. Ministry of Agriculture of the Republic of Indonesia. Modernisasi tingkatkan produktivitas tenaga kerja sektor pertanian [Internet]. Jakarta; 2019. Available from: https://www.pertanian. go.id/home/?show=news\&act=view\&id=3839

8. M.S.A. Majid, H. Maulana. Gadjah Mada Int. J. Bus.14, 2 (2010)

9. A. Mathur, M.I. Mittal, G.S. Dangayach. Prod. Plan. Control. 23, 10-11 (2012)

10. B.H. Hall, F. Lotti, J. Mairesse. Small Bus. Econ. 33, 1 (2009)

11. D. Emine. J. Contemp. Manag. 1, 9 (2012)

12. P.A Igwe, A.N.A.O.M. Ogundana, O.M. Egere, J.A. Anigbo. Eur. J. Sustain. Dev. 7, 1 (2018)

13. S. Cao, D. Leung. Econ. Model. 88 (2020).

14. E. Calza, M. Goedhuys, N. Trifković. Econ. Innov. New. Technol. 28, 1 (2019)

15. J.W Lee, N. Suwimol. J. Transnatl. Manag. 23, 4 (2018)

16. S.C.R. Erazo, D.A Paz, J.A. Cardona. Contribution of information technology and communications to productivity in SMEs in Santiago de Cali, in Proceeding of the 15th Iberian Conference on Information Systems and Technologies (CISTI), 15. IEEE (2020)

17. J.G. Vargas-Hernández. Innovation of SMEs and their effect on productivity in Jalisco, in Innovation Management and Growth in Emerging Economies. IGI Global, 155-91 (2020)

18. L. Cusmano, M. Koreen, L. Pissareva. 2018 OECD ministerial conference on SMEs: Key issues paper, in OECD SME and Entrepreneurship Paper. Paris (2018)

19. D. Kurniawati, H. Yuliando. Agric. Sci. Procedia. 3 (2015)

20. T. Suminar, A. Yusuf. People Int. J. Soc. Sci. 6, 1 (2020)

21. J.T. Wengel, E. Rodriguez. Small Bus. Econ. 26, 1 (2006)

22. A. Parameswara, A. Wulandari, R. Giri. Int. J. Bus. Econ. Law. 18, 5 (2019).

23. I.R Bawono, T. Arofah, B.M.S. Ubay. J. Ilm. Mana. Ekon. Akun. 4, 3 (2020)

24. S.U.J. Raharja, N. Kostini, H.A. Muhyi, R. Rivani. Int. J. Trade Glob. Mark. 12, 3-4 (2019)

25. W.W. Cooper, L. Seiford. Handbook on Data Envelopment Analysis. Zhu J, editor. Boston: Boston, MA: Springer Science \& Business Media (2011)

26. M.A. Omar, A.R.A. Rahman, R.M. Yusof, M.S.A. Majid, M.E.S Rasid. Asian Acad. Manag. J. Account. Financ. 2, 2(2006)

27. T. Coelli. A guide to DEAP version 2.1 data envelopment analysis (computer) program, in CEPA Working Paper. Report No.: 96/98, Armdale (1996)
28. R.D Banker, A. Charnes, W.W. Cooper. Manage. Sci. 30, 9 (1984)

29. S. Sulikah. Analisis efisiensi koperasi pegawai negeri Republik Indonesia Kabupaten Klaten. Thesis. Universitas Sebelas Maret (2010)

30. G. Syamni, M.S.A. Signifikan J. Ilmu Ekon. 2, 5(2016)

31. F. Dong, A.M. Featherstone. J. Chinese Econ. Bus. Stud. 1, 4 (2006)

32. P. Asawaruangpipop, O. Suwunnamek. Res. J. Bus. Manag. 3, 8(2014)

33. I. Hasan, A. Azhari, M.S.A Majid. REVESCO Rev. Estud. Coop. 128 (2018)

34. M.S.A Majid, F. Faisal, H. Fahlevi, A. Azhari. Measuring and decomposing SMEs' productivity in creative economic sector in Indonesia, in IOP Conf. Ser: Earth and Envir. Sci. IOP Publishing (2012) 